\title{
Estimating population cause-specific mortality fractions in the Islamic Republic of Iran: validation of Murray's method
}

Abbas Alipour, ${ }^{1}$ Soheila Khodakarim, ${ }^{2}$ Ardeshir Khosravi, ${ }^{3}$ and Amin Ataey ${ }^{2}$

${ }^{1}$ Thalassemia Research Center, Mazandaran University of Medical Sciences, Sari, Islamic Republic of Iran. ${ }^{2}$ Department of Epidemiology, School of Public Health, Shahid Beheshti University of Medical Sciences, Tehran, Islamic Republic of Iran. ${ }^{3}$ Deputy for Public Health, Ministry of Health and Medical Education and Medical Education, Tehran, Islamic Republic of Iran. (Correspondence to: Amin Ataey: amin 5143@yahoo.com)

\begin{abstract}
Background: Vital civil information is recorded in only $25 \%$ of middle-income countries.

Aims: To estimate the number and causes of deaths expected in the population, using hospital mortality data and comparing them with data from the Ministry of Health and Medical Education, Tehran, Islamic Republic of Iran.
\end{abstract}

Methods: Hospital mortality data for 2011-2015 were extracted and were corrected qualitatively through reference to medical records. Using Murray's proposed method, an estimate of the expected deaths was obtained according to cause of death.

Results: During 2011-2015, 12704 deaths were recorded in the hospital and Murray's method estimated 28768 deaths for the entire population. The most frequent cause of death was ischemic heart disease. The results were compared with data from the Ministry of Health and Medical Education, which had a relative error of $6.9 \%$ and $-13.5 \%$ respectively. The mortality rates registered by the Civil Registration Office were higher than those estimated in the present study. The mortality rates registered by the Ministry of Health and Medical Education were lower than those in the present study.

Conclusions: Considering the importance of registering deaths, alternative methods, with efficiency and low cost, are needed to estimate the number and causes of death in a population.

Keywords: cause-specific mortality rate, estimated mortality, hospital mortality, Islamic Republic of Iran, Murray's method

Citation: Alipour A; Khodakarim S; Khosravi A; Ataey A. Estimating population cause-specific mortality fractions in the Islamic Republic of Iran: validation of Murray's Method. East Mediterr Health J. 2020;26(3):290-296. https://doi.org/10.26719/emhj.19.031

Received: $28 / 10 / 17$; accepted: $28 / 06 / 18$

Copyright (c) World Health Organization (WHO) 2020. Open Access. Some rights reserved. This work is available under the CC BY-NC-SA 3.0 IGO

license (https://creativecommons.org/licenses/by-nc-sa/3.o/igo).

\section{Introduction}

Frequency and causes of mortality are important components in the health planning of communities (1). Timely registration of deaths and correct record keeping form the basis of demographic analysis (2). In order to monitor epidemiological changes in disease, the health sector relies heavily on the proper functioning of such vital records and statistics (3). Changes in trends of the causes of mortality over time determine the direction of a country's health policies. Mortality among different age and sex groups indicates the status of health services and the health status of different groups in society (4). Despite the importance of information about the causes of mortality, data availability and accuracy are limited in many countries (5). Vital information is recorded in only $25 \%$ of middle-income countries and $5-10 \%$ of low-income countries $(6,7)$.

In the Islamic Republic of Iran, various institutions are responsible for registering vital events such as the Civil Registration Office and the Ministry of Health and Medical Education. In addition to these institutions, regarding death registration, the forensic organization has taken some measures and collected useful information on specific causes of death (8). The Civil Registration Office and the Ministry of Health and Medical Education have always had a percentage of errors in collecting mortality data for several reasons. The vast majority of information collected by demographic experts in the Islamic Republic of Iran, in relation to mortality rates and disagreements in this regard, confirms the failure in accurate registration of death (9).

Studies of the extent and causes of mortality in the Islamic Republic of Iran and many other countries have indicated their direct relation with the level of health and development in the countries. Therefore, such research has a major effect on programmes aimed at promoting community health and livelihood (10).

A similar study by Murray et al. was conducted based on data available in Mexico, in which hospital deaths registered were used to estimate the causespecific mortality rate in the whole population with the minimum rate of error (11). This highlighted certain novel approaches to estimating cause-specific mortality fractions with data on cause of death collected from different institutions. The Islamic Republic of Iran is also one of the countries that Murray et al. mentioned that has potential for applying the method. In addition, the results of studies by Khosravi et al. (12) and Komijani et al. (13) point out the low registration of deaths in countries that use various statistical methods.

Using the Murray method, and considering that data available in hospitals are the most suitable and accessible source for determining the cause of death, the 
distribution of the expected mortality was determined based on the international coding of diseases in the whole population of Ardebil (Northwest Islamic Republic of Iran) by sex, age and cause of death. Ardebil Province covers $17953 \mathrm{~km} 2$ and its population is 1270420 based on the 2016 census (https://www.amar.org.ir).

In a review of the Human Development Index, Ardebil Province scored 0.692 (middle ranking); for the whole country the Index was 0.742 . The effective factors in this index include life expectancy, literacy rate, and per capita income. These data, including distribution of mortality in Ardebil Province by age, sex and cause of mortality, can be used in regional health decision-making as well as for intervention measures and improvements in mortality registration and reporting systems in the province.

\section{Methods}

\section{Data collection}

This was a descriptive-analytical study. Mortality data for 2011-2015 were extracted from the Civil Registration Office and the Death Registration System of the Ministry of Health and Medical Education, Tehran, Islamic Republic of Iran, hospitals in Ardebil Province, and Ardebil University of Medical Sciences. The hospital mortality data were collected in accordance with the regulatory checklist. Data were subsequently investigated quantitatively and qualitatively and in terms of the cause of death. In cases where the required information was not correctly registered, the quality of the data was improved by using the medical records of the deceased. The mortality rate was calculated based on the proposed Murray method. We compared this information with the data registered in the Ardebil Province Civil Registration Office and Ministry of Health and Medical Education and obtained the percentage of relative error by year, which was compared with the actual information recorded.

\section{Information analysis}

The results were calculated using Excel and the proposed Murray method using the following formula (11):

$\mathrm{D}_{a s j}=\frac{\mathrm{H}_{a s j}}{\mathrm{P}_{a s j}}$

$\mathrm{D}_{a s j}$ is the total death rate for the age group $a$, sex $s$, and the cause of death $\mathrm{j} . \mathrm{H}_{a s j}$ is the mortality rate in the hospital for the age group $a$, sex $s$, and the cause of death $j . \mathrm{P}_{a s j}$ is the ratio of death in the hospital for age group $a$, sex $s$, and cause of death $j$. The relative error percentage was calculated based on the following formula:

Relative error percentage $=\frac{\text { Actual amount-Test result }}{\text { Actual amount }} \times 100$

It should be noted that due to the lack of any similar study in the Islamic Republic of Iran and the lack of access to mortality ratios in hospitals, Murray's study ratios were used in this research.

\section{Ethical considerations}

Ethical clearance for this study was received from the School of Public Health, Shahid Beheshti University of Medical Sciences, Tehran, Islamic Republic of Iran (reference IR.SBMU.PHNS.REC.2016.141).

\section{Results}

There were 12704 deaths in the hospitals in Ardebil Province from 2011 to 2015 , covering all age groups; of which, 7341 cases were male $(57.8 \%$ ) and 5363 female (42.2\%), with a male to female ratio of 1.36 (Table 1 ). The mean (SD) age of death in men was 55.19 (28.72) years compared with 57.29 (29.42) years in women. In the 1-28 days and 15-64 years age groups, the mean age at death was significantly higher in women than in men $(P<0.05)$. There were no significant sex differences in the main age at death in the other age groups.

Table 2 shows the specific estimates of the cause of death obtained using the proposed Murray method. From 2011 to 2015, the rate of expected deaths for the population was 5747.2, 5861.8, 5739.2, 5574.1 and 5845.7. The leading cause of mortality in all years of the study was ischemic heart disease. Other causes of death according to Murray's estimation included: other cardiovascular diseases, hypertension, cerebrovascular disease, other unintentional events, stomach cancer, other malignant neoplasms, other respiratory diseases, lung cancer, low birth weight, birth asphyxia, and birth trauma.

Table 3 shows the relative error percent of the data registered in the Ardebil Province Civil Registration Office in relation to the information based on the proposed

\begin{tabular}{|c|c|c|c|c|c|}
\hline \multirow[t]{2}{*}{ Age groups } & \multicolumn{2}{|c|}{ Number (\%) } & \multicolumn{2}{|c|}{ Average age (SD) } & \multirow[t]{2}{*}{$\mathbf{P}$} \\
\hline & Men & Women & Men & Women & \\
\hline 28 days & $842(55.1)$ & $685(44.9)$ & $2.79(5.08)$ & $3.41(5.99)$ & 0.029 \\
\hline$<1$ year & $962(55.4)$ & $773(44.6)$ & $0.46(1.62)$ & $0.44(1.58)$ & 0.712 \\
\hline$<5$ years & $1045(55.4)$ & $840(44.6)$ & $2.79(8.85)$ & $2.89(9.5)$ & 0.821 \\
\hline$<15$ years & $1116(56.6)$ & $891(44.4)$ & $0.75(2.42)$ & $0.73(2.44)$ & 0.893 \\
\hline $15-64$ years & $2384(62.3)$ & $1441(37.7)$ & $46.74(13.75)$ & $48.99(13.1)$ & $<0.001$ \\
\hline$\geq 65$ years & $3841(55.9)$ & $3031(44.1)$ & $77.63(7.04)$ & $77.85(7.30)$ & 0.213 \\
\hline Total & $7341(57.8)$ & $5363(42.2)$ & $55.91(28.72)$ & $57.28(29.42)$ & 0.009 \\
\hline
\end{tabular}




\begin{tabular}{|c|c|c|c|c|c|}
\hline Cause of death & 2011 & 2012 & 2013 & 2014 & 2015 \\
\hline Diabetes mellitus & 145.7 & 121.4 & 108.3 & 147.6 & 138.2 \\
\hline Ischemic heart disease & 1141.6 & $1477 \cdot 3$ & 911.7 & 1284.4 & 1300.2 \\
\hline Cerebrovascular disease & 408.6 & 454.8 & 399.3 & 445.6 & 589.8 \\
\hline Liver diseases & 22.6 & 32.1 & 5.7 & 15.1 & 15.1 \\
\hline Other unintentional injuries & 310.0 & 281.2 & 151.4 & 194.7 & 165.8 \\
\hline Other cardiovascular diseases & 606.1 & 385.5 & 764.3 & 465.7 & 603.8 \\
\hline Chronic obstructive pulmonary disease & 70.0 & 45.2 & 31.6 & 24.8 & 56.4 \\
\hline Lower respiratory infections & 36.3 & 74.7 & 23.5 & 25.6 & 25.6 \\
\hline Other malignant neoplasms & 228.3 & 279.9 & 220.4 & 301.8 & 331.5 \\
\hline Other digestive diseases & 38.2 & 32.7 & 25.9 & 42.3 & 31.4 \\
\hline Intentional injuries & 68.9 & 85.1 & 93.2 & 93.2 & 93.2 \\
\hline Nutritional deficiencies & 10.3 & 0.0 & 3.4 & 3.4 & 3.4 \\
\hline Hypertensive diseases & 461.2 & 633.6 & 675.5 & 398.3 & 510.1 \\
\hline Road traffic accidents & 110.5 & 153.6 & 97.0 & 110.5 & 64.7 \\
\hline Nephritis and Nephrosis & 96.8 & 100.5 & 56.6 & 62.1 & 67.6 \\
\hline Perinatal respiratory disorders & 26.0 & 18.1 & 29.4 & 30.5 & 79.1 \\
\hline Ill-defined malignant neoplasms & 87.8 & 112.9 & 150.5 & 112.9 & 117.9 \\
\hline Breast and cervical cancer & 33.5 & 44.7 & 41.9 & 25.1 & 25.1 \\
\hline Other respiratory diseases & 152.4 & 169.6 & 122.3 & 124.5 & 182.1 \\
\hline Ill-defined causes & 529.5 & 162.3 & 503.8 & 42.7 & 0.0 \\
\hline Other neuropsychiatric conditions & 83.0 & 78.1 & 92.8 & 136.7 & 102.5 \\
\hline Other noncommunicable disease & 53.8 & 3.8 & 51.9 & 53.8 & 21.1 \\
\hline Lung cancer & 151.3 & 159.3 & 98.2 & 127.4 & 169.9 \\
\hline Endocrine disorders & 15.5 & 22.4 & 46.4 & 41.3 & 27.5 \\
\hline Stomach cancer & 286.2 & 347.5 & 255.5 & 374.8 & 357.8 \\
\hline Other congenital anomalies & 26.6 & 46.8 & 27.8 & 86.0 & 50.6 \\
\hline Diarrhoea-related diseases & 1.9 & 11.7 & 7.8 & 1.9 & 1.9 \\
\hline HIV & 1.6 & 0.0 & 1.6 & 3.2 & 1.6 \\
\hline Liver cancer & 92.8 & 72.9 & 96.1 & 62.9 & 69.6 \\
\hline Congenital heart anomalies & 29 & 25.2 & 58.0 & 61.8 & 17.7 \\
\hline Prostate cancer & 36.7 & 91.8 & 73.4 & 51.4 & 51.4 \\
\hline Alcohol use & 0.0 & 3.0 & 3.0 & 0.0 & 0.0 \\
\hline Other infectious and parasitic diseases & 30.3 & 17.9 & 23.4 & 93.7 & 62.0 \\
\hline Septicaemia & 26.8 & 4.9 & 20.7 & 3.7 & 0.0 \\
\hline Tuberculosis & 8.7 & 3.5 & 12.2 & 7.0 & 1.7 \\
\hline Low birth weight, birth asphyxia, and birth trauma & 150.5 & 160.7 & 161.9 & 240.5 & 237.1 \\
\hline Perinatal infections & 2.1 & 1.1 & 2.1 & 2.1 & 4.2 \\
\hline Other neoplasms & 9.4 & 1.6 & 47.1 & 56.5 & 11.0 \\
\hline Pancreas cancer & 19.5 & 25.1 & 16.7 & 33.4 & 27.9 \\
\hline Colon/rectum cancer & 69.4 & 61.3 & 82.7 & 80.0 & 82.7 \\
\hline Cirrhosis of the liver & 8.0 & 12.0 & 15.9 & 8.0 & 8.0 \\
\hline Other perinatal conditions & 40.2 & 24.1 & 63.2 & 72.4 & 73.6 \\
\hline Haematemesis, melaena and gastrointestinal haemorrhage & 7.1 & 6.5 & 6.5 & 0.0 & 5.6 \\
\hline Ill-defined injuries & 8.1 & 10.9 & 19.0 & 19.0 & 51.6 \\
\hline Other communicable and maternal conditions & 4.3 & 5.7 & 40.1 & 5.7 & 11.5 \\
\hline
\end{tabular}




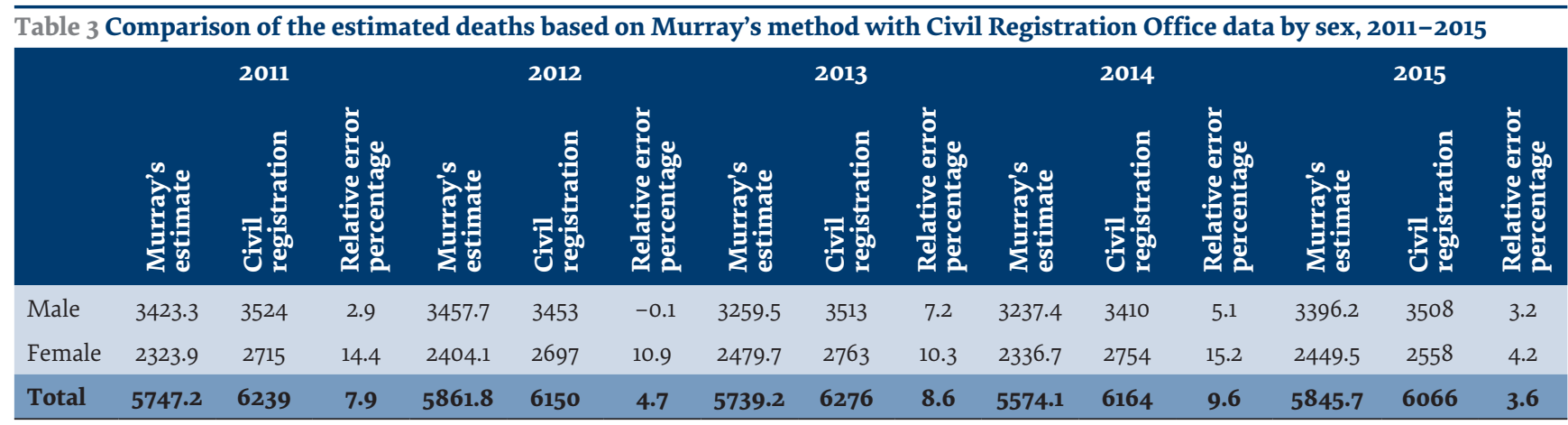

Table 4 Comparison of the estimated deaths based on Murray's method with Ministry of Health and Medical Education data by sex, 2011-2015

\begin{tabular}{|c|c|c|c|c|c|c|c|c|c|c|c|c|c|c|c|}
\hline & \multicolumn{3}{|c|}{2011} & \multicolumn{3}{|c|}{2012} & \multicolumn{3}{|c|}{2013} & \multicolumn{3}{|c|}{2014} & \multicolumn{3}{|c|}{2015} \\
\hline & 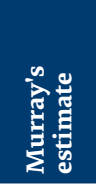 & 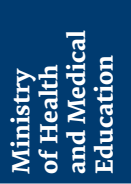 & 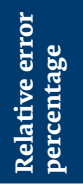 & 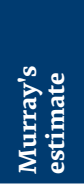 & 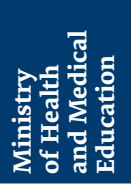 & 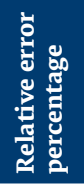 & 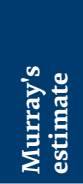 & 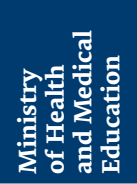 & 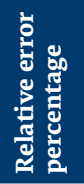 & 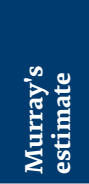 & 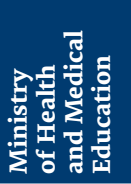 & 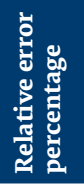 & 总总 & 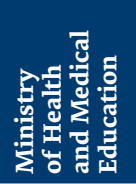 & 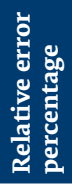 \\
\hline Male & 3423.3 & 2782 & -23.0 & 3457.7 & 2825 & -22.4 & 3259.5 & 2856 & -14.1 & 3237.4 & 3003 & -7.8 & 3396.2 & 3223 & -5.4 \\
\hline Female & 2323.9 & 1964 & -18.3 & 2404.1 & 2003 & -20.0 & 2479.7 & 2112 & -17.4 & 2336.7 & 2226 & -5.0 & 2449.5 & 2350 & -4.2 \\
\hline otal & 5747.2 & 4746 & -21.1 & 5861.8 & 4828 & -21.4 & 5739.2 & 4968 & -15.5 & 5574.1 & 5229 & -6.6 & 5845.7 & 5573 & \\
\hline
\end{tabular}

Murray method by sex and age. The relative error percent for 2011-2015 was 7.9, 4.7, 8.6, 9.6 and 3.6\%, respectively. Among men the smallest difference was observed in 2012 with $-0.1 \%$, and the largest difference was in 2013 with $7.2 \%$. Among women, the smallest difference of $4.2 \%$ was in 2015 , and the largest difference of $15.2 \%$ was in 2014 . The mortality rates registered by the Civil Registration Office were higher than those estimated in the present study.

Table 4 shows the difference between the data registered in Ardebil Ministry of Health and Medical Education and the information based on the proposed Murray method categorized by sex and age. The smallest difference was $-4.9 \%$ in 2015 and the highest difference was $-21.4 \%$ in 2012. Among men, the smallest difference was $-5.4 \%$ in 2015 and the largest difference was $-23 \%$ in 2011. Among women, the smallest difference was $-4.2 \%$ in 2015 and the largest difference was $-20 \%$ in 2012 . In all years of the study, the mortality rates registered by Ardebil Ministry of Health and Medical Education were lower than those in the present study.

Figure 1 shows the obtained relative error percentage from a comparison of the Murray method results with the information from the Civil Registration Office and Ministry of Health and Medical Education over 5 years, which indicates the improvement in information registration. During this period the number of registered deaths in the Civil Registration Office was 6.9\% higher compared to the Murray method estimation, while Ardebil Ministry of Health and Medical Education has $-13.5 \%$ fewer registrations.

\section{Discussion}

Registering vital events, especially mortality, is essential in order to research the causes of premature death and plan effectively for health promotion programmes. The mortality rate in hospitals in Ardebil from 2011 to 2015 showed a male to female ratio of 1.36. Among all hospital deaths, $57.8 \%$ were male and $42.2 \%$ female. Studies by Foruzanfar et al. (14), Tariq et al. (15) and Pattaraarchachai et al. (16) showed similar results in terms of the sex ratio of the deceased. Khosravi et al. (2015) (17) also reported a male/female sex ratio of 1.37 among the deceased and $57.9 \%$ of deaths were in men and $42.1 \%$ in women. Moore and Wilson (18) suggested that men are more likely to die from parasitic and infectious diseases than women are, which may be due to differences in male and female immunity to these infections.

In the United States of America, United Kingdom of Great Britain and Northern Ireland, and Japan, men are twice as likely as women to die from parasitic diseases (19). Men also demonstrate more high-risk behaviours such as violence, accidents and suicide (20). Other studies also showed that the average age of death due to accidents, events and cardiovascular disease in men was lower than in women, which explains the difference in age between the sexes, which is consistent with the results of the present study (21-23).

In the present study, we found that the estimated mortality rate in all study years was higher than that registered by the Ministry of Health and Medical Education, which was consistent with previous studies 


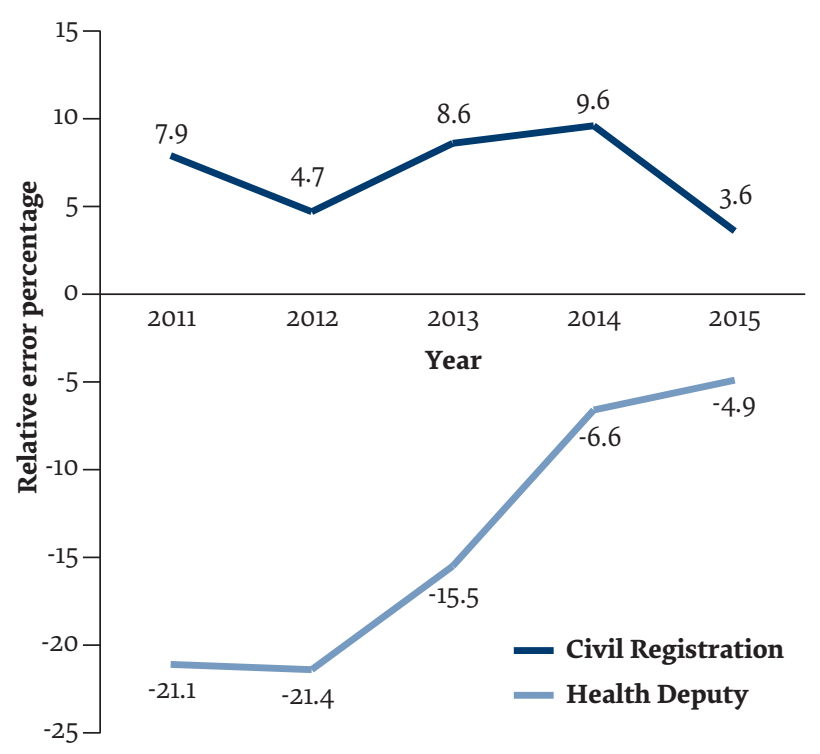

Figure 1 Relative error percentage in the Murray's estimate compared with the Ministry of Health and Medical Education and Civil Registration, 2011-2015

$(9,11,13,24,25)$. However, the estimated mortality rate in our study was lower than that registered by the Civil Registration Office. Given that the causes of mortality in a large number of hospital deaths, especially in the early years, were unclear, these cases were placed in the other causes group and were probably related to the most common causes of death (such as cardiovascular diseases). Clearly, by improving the hospital registration system, it can be expected that the ratio of other causes will be reduced and added to the main groups. Therefore, this study demonstrated that the population mortality estimation was more accurate than that derived from the hospital data and the relative error rate relative to mortality compiled by the Civil Registration Office decreased.

One of the major obstacles to an effective death registration system in the Islamic Republic of Iran is that the responsible authorities act individually and in isolation. Based on the experiences of the electronic system for registration of mortality in high-income countries, which have a central database, we recommend creation of a centralized meta-electronic registration system in the country.

Given the low level of registration of deaths between 2011 and 2015 indicated in this study, and the importance of information registration in health decision-making and policy-making, the current registration system seems unable to provide adequate information for the development of health programmes in the Islamic Republic of Iran. Therefore, alternative, low-cost and timeous methods are needed to enable descriptive epidemiological estimation of the population. The method used in this study has the advantage of comparing the expected rate of mortality in the form of cause-specific mortality groups, which play a significant role in decision-making and formulating health policies.

\section{Acknowledgements}

The present study is a part of a Masters dissertation in epidemiology from the School of Public Health, Shahid Beheshti University of Medical Sciences, Tehran, Islamic Republic of Iran.

Funding: None.

Competing interests: None declared.

\section{Estimation des écarts en matière de mortalité par cause spécifique dans la population de la République islamique d'Iran : validation de la méthode de Murray \\ Résumé}

Contexte : Les faits d'état civil sont enregistrés dans seulement $25 \%$ des pays à revenu intermédiaire.

Objectifs : Estimer le nombre de décès prévus dans la population et leurs causes, en exploitant les données des hôpitaux sur la mortalité et en les comparant avec celles du ministère de la Santé et de l'Éducation médicale et du Bureau d'état civil de Téhéran (République islamique d'Iran).

Méthodes : Les données relatives à la mortalité hospitalière pour la période 2011-2015 ont été extraites, puis corrigées d'un point de vue qualitatif par rapport aux dossiers médicaux. En utilisant la méthode proposée par Murray, une estimation de la mortalité prévue a été obtenue selon la cause du décès.

Résultats : Entre 2011 et 2015, 12704 décès ont été enregistrés à l'hôpital, et la méthode de Murray a permis d'estimer 28768 décès pour la population complète. La cause de décès la plus fréquente était la cardiopathie ischémique. Les résultats ont été comparés aux données du ministère de la Santé et de l'Éducation médicale et du Bureau d'état civil, qui montraient des taux d'erreur relative respectifs de 6,9\% et - $13,5 \%$. Les taux de mortalité enregistrés par le Bureau d'état civil étaient supérieurs à ceux estimés par la présente étude. Les taux de mortalité enregistrés par le ministère de la Santé et de l'Éducation médicale étaient inférieurs à ceux de la présente étude. 
Conclusions : Compte tenu de l'importance de l'enregistrement des décès, des méthodes alternatives, efficaces et économiques, sont requises pour estimer le nombre de décès et leurs causes au sein d'une population.

$$
\begin{aligned}
& \text { تقدير الأرقام الكسرية للوفيات التي تُعَىى لأسبابِ محددة في جمهورية إيران الإسلامية: التحقق باستخدام طريقة } \\
& \text { موراي } \\
& \text { عباس عليبور، سهيلة خودا كريم، آردشير خسروي، أمين عطائي } \\
& \text { الخالاصة }
\end{aligned}
$$

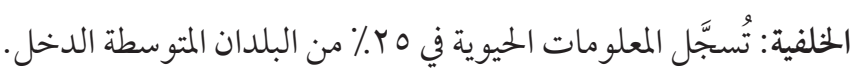

$$
\begin{aligned}
& \text { الأهداف: هدفت الدراسة إلى تقدير عدد الوفيات المتوقعة بين السكان وأسبابها، باستخدام بيانات الوفيات الواردة من المستشفيات ومقارنتها }
\end{aligned}
$$

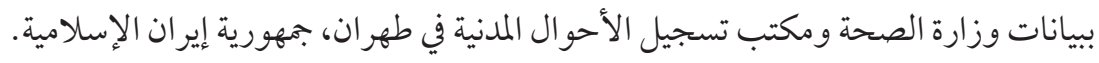

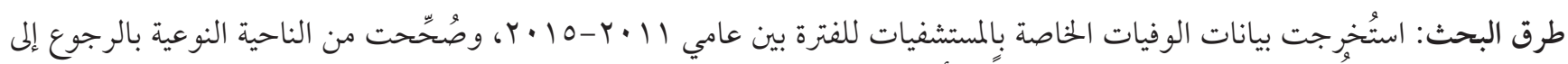

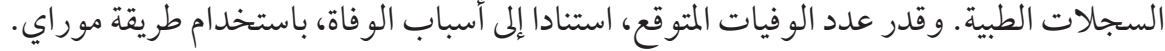

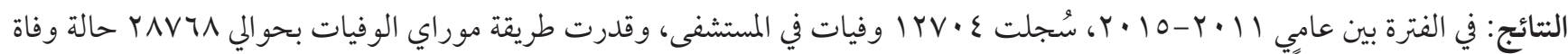

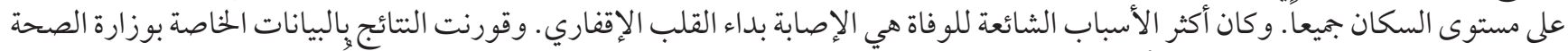

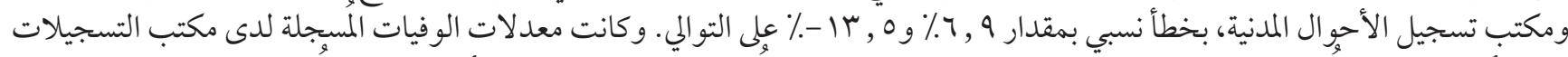

$$
\begin{aligned}
& \text { المدنية أعلى من تلك المقدرة في هذه الدراسة. بينما كانت معدلات الوفيات المستجلة للدى وزارة الصحة أقلى من تلك المقدرة في هذه الدراسة. } \\
& \text { الاستنتاجات: بالنظر إلى أهمية تسجيل الوفيات، يلزم استخدام طرق بديلة فعالة ومنخفضة التكلفة لتقدير عدد الوفيات في صفوف السكان } \\
& \text { وأسبابها. }
\end{aligned}
$$

\section{References}

1. Yavari P, Abadi A, Mehrabi YE. Mortality and changing epidemiological trends in Iran during 1979-2001. Hakim Res J. 2003 Fall;6(3):7-14. https://www.sid.ir/en/journal/ViewPaper.aspx?id=62603

2. Principles and recommendations for a vital statistics system. Revision 2. New York: United Nations; 2001 (http://unstats.un.org/ unsd/publication/SeriesM/SeriesM_19rev2E.pdf, accessed 5 August 2019).

3. Mehrabi Y, Khosravi A. The analysis of the components of the health information system of the Islamic Republic of Iran in 1393. (in Persian).

4. Naghavi M. Condition death in four provinces. Tehran: Ministry of Health and Medical Education and Medical Education; 1999 (in Persian).

5. Hill K, Vapattanawong P, Prasartkul P, Porapakkham Y, Lim SS, Lopez AD. Epidemiologic transition interrupted: a reassessment of mortality trends in Thailand, 1980-2000. Int J Epidemiol. 2007 Apr;36(2):374-84. https://doi.org/10.1093/ije/dyl257 PMID:17182635

6. Mathers $\mathrm{CD}, \mathrm{Ma}$ Fat D, Inoue M, Rao C, Lopez AD. Counting the dead and what they died from: an assessment of the global status of cause of death data. Bull World Health Organ. 2005 Mar;83(3):171-7. http://dx.doi.org/10.1590/So042-96862005000300009 PMID:15798840.

7. Lopez AD, Saloman J, Ahmad O, Murray CJL, Mafat D. Life tables for 191 countries for 2000: data, methods, results. Geneva: World Health Organization; 2001 (GPE Discussion Paper Series: No. 9; https://www.who.int/healthinfo/paperog.pdf, accessed 5 August 2019)

8. Sadoghi F, Samadbic M. Health information technology. Tehran: Jafari Pub; 2012 (in Persian).

9. Jabarian A. Comparison of mortality registration system between the two census organization and the Ministry of Health and Medical Education and medical education of the records at the city of karaj.: Islamic Azad University of Tehran; 1385. (in Persian).

10. Jafari N. (unpublished). Mortality profile for 29 provinces of Iran (2006). Iranian Ministry of Health and Medical Education and Medical Education.

11. Murray CJ, Lopez AD, Barofsky JT, Bryson-Cahn C, Lozano R. Estimating population cause-specific mortality fractions from in-hospital mortality: validation of a new method. PLoS Med. 2007 Nov 20;4(11):e326. https://doi.org/10.1371/journal. pmed.0040326 PMID:18031195

12. Khosravi A, Taylor R, Naghavi M, Lopez AD. Mortality in the Islamic Republic of Iran, 1964-2004. Bull World Health Organ. 2007 Aug;85(8):607-14. http://dx.doi.org/10.1590/So042-96862007000800013 PMID:17768519 
13. Komeijani A, Kosheshi M, Niakan L. Iran mortality rates using Lee-Carter Model: estimation and forecasting. Sanaat E Bimeh. 2014 Winter;28(4):1-25 (in Persian). https://www.sid.ir/en/journal/ViewPaper.aspx?id=501830

14. Forouzanfar MH, Sepanlou SG, Shahraz S, Dicker D, Naghavi P, Pourmalek F, et al. Evaluating causes of death and morbidity in Iran, global burden of diseases, injuries, and risk factors study 2010. Arch Iran Med. 2014 May;17(5):304-20. http://dx.doi. org/0141705/AIM.004 PMID: 24784860

15. Tariq M, Jafri W, Ansari T, Awan S, Ali F, Shah M, et al. Medical mortality in Pakistan: experience at a tertiary care hospital. Postgrad Med J. 2009 Sep;85(1007):470-4. http://dx.doi.org/10.1136/pgmj.2008.074898 PMID: 19734514

16. Pattaraarchachai J, Rao C, Polprasert W, Porapakkham Y, Pao-in W, Singwerathum N, et al. Cause-specific mortality patterns among hospital deaths in Thailand: validating routine death certification. Population Health Metrics. 2010;8:Article number 12. https://doi.org/10.1186/1478-7954-8-12

17. Khosravi A, Aghamohamadi S, Kazemi E. Mortality profile in the Islamic Republic of Iran 2015 (20 leading cause of death by sex and age group). Tehran: Ministry of Health and Medical Education and Medical Education; 2015.

18. Moore SL, Wilson K. Parasites as a viability cost of sexual selection in natural populations of mammals. Science. 2002 Sep 20;297(5589):2015-8. http://dx.doi.org/10.1126/science.1074196 PMID:12242433

19. Owens IP. Sex differences in mortality rate. Science. 2002 Sep 20;297(5589):2008-9. http://dx.doi.org/10.1126/science.1076813

20. World Health Statistics. Geneva: World Health Organization; 2001.

21. Akbari M, Naghavi M, Soori H. Epidemiology of deaths from injuries in the Islamic Republic of Iran. East Mediterr Health J. 2006 May-Jul;12(3-4):382-90. PMID: 17037707

22. Pop C, Pop L, Dicu D. Epidemiology of acute myocardial infarction in Romanian county hospitals: a population-based study in the Baia Mare district. Rom J Intern Med. 2004; 42(3):607-23. PMID:16366134

23. Kubota I, Ito H, Yokoyama K, Yasumura S, Tomoike H. Early mortality after acute myocardial infarction: observational study in Yamagata, 1993-1995. Jpn Circ J. 1998 Jun;62(6):414-8. PMID:9652316

24. Khosravi A, Taylor R, Naghavi M, Lopez AD. Differential mortality in Iran. Population Health Metrics. 2007;5:Article number 7. https://doi.org/10.1186/1478-7954-5-7

25. Zanjani H. (unpublished). The plan for assessing the information recording system of vital events (birth, death and internal migration) location-based 2013 (in Persian). 